\title{
Editorial
}

The Mainzer Historische Kulturwissenschaften [Mainz Historical Cultural Sciences] series publishes the results of research that develops methods and theories of cultural sciences in connection with empirical research. The central approach is a historical perspective for cultural sciences, whereby both epochs and regions can differ widely and be treated in an all-embracing manner from time to time. The series brings together, among other things, research approaches in archaeology, art history and visualistic, philosophy, literary studies and history, and is open for contributions on the history of knowledge, political culture, the history of perceptions, experiences and life-worlds, as well as other fields of research with a historical cultural scientific orientation.

The objective of the Mainzer Historische Kulturwissenschaften series is to become a platform for pioneering works and current discussions in the field of historical cultural sciences.

The series is edited by the Co-ordinating Committee of the Special Research Group Historical Cultural Sciences (HKW) at the Johannes Gutenberg University Mainz. 
JÖRG ROGGE (ED.)

\section{Cultural History in Europe}

Institutions - Themes - Perspectives

[transcript] 
The Conference on Cultural History in Europe was sponsored by the DFG. The Print was sponsored by the Research Focus Historical Cultural Sciences (HKW).

\section{Bibliographic information published by the Deutsche Nationalbibliothek}

The Deutsche Nationalbibliothek lists this publication in the Deutsche Nationalbibliografie; detailed bibliographic data are available in the Internet at http://dnb.d-nb.de

\section{(ㄷ) 2011 transcript Verlag, Bielefeld}

All rights reserved. No part of this book may be reprinted or reproduced or utilized in any form or by any electronic, mechanical, or other means, now known or hereafter invented, including photocopying and recording, or in any information storage or retrieval system, without permission in writing from the publisher.

Cover layout: Kordula Röckenhaus, Bielefeld

Proofread by Cathleen Sarti, Mainz

Typeset by Justine Haida, Bielefeld

Printed by Majuskel Medienproduktion GmbH, Wetzlar

ISBN 978-3-8376-I724-5

Global distribution outside Germany, Austria and Switzerland:

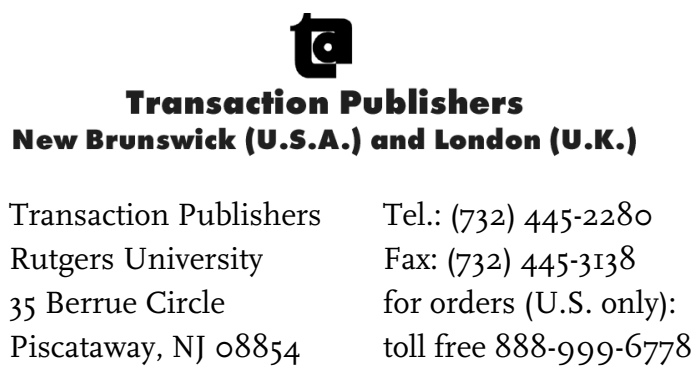

